82 Literatura e Sociedade

\title{
MuRILO Mendes nOS JoRnals: ENTRE A POLÍTICA E A RELIGIÃO
}

\author{
Maria Betânia Amoroso \\ Universidade Estadual de Campinas
}

\section{Resumo}

O artigo parte da série de artigos escritos por Murilo Mendes para o jornal Dom Casmurro em 1937 e insere o poeta entre os intelectuais católicos, uma das forças constitutivas da política no Brasil, em um período de acirradas polêmicas. Fazendo-se porta-voz de posições avançadas do catolicismo, de matriz francesa, o poeta propõe, com veemência, que esse seja o caminho da modernização da sociedade brasileira. A partir da década de 1950 , vivendo na Itália, a presença do catolicismo na obra de Murilo diminui. Entretanto, alguns importantes nomes da crítica Oreste Macrì, Ruggero Jacobbi e Mario Luzi - irão associar sua obra à vertente italiana da lírica moderna, o hermetismo, no qual as noções de catolicismo, civilização e poesia são intercambiáveis e unificadas em um projeto que se quer universal e eterno.

\section{Abstract}

This article begins with the set of articles written by Murilo Mendes to Dom Casmurro newspaper in 1937 and finds a place to the poet among catholic intellectuals, one of the constitutive forces of the politics in Brazil, in a period of intense polemics. Being a spokesman of advanced tendencies of the Catholicism, whose origin was French, he strongly proposes that as the path to the modernization of brazilian society. From 1950's on, living in Italy, the presence of the Catholicism in Murilo's writings gets weaker. Some important names of his criticism, nevertheless, like Oreste Macrì, Ruggero Jacobbi e Mario Luzi, will associate his books to the Italian tendency of modern lyric, the hermeticism, in which the conceptions of Catholicism, civilization and poetry are interchangeable and unified in a project that wants to be universal and eternal.
Palavras-chave

Pensamento católico; poesia; crítica.

\author{
Keywords \\ Catholic \\ thought; poetry; \\ criticism.
}




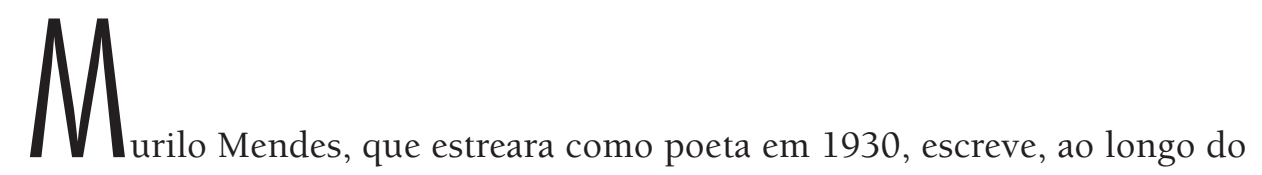
ano de 1937, uma série de artigos para o jornal carioca Dom Casmurro. ${ }^{1}$

Outras dessas séries de artigos, mais amplas, sempre escritas para jornais, já foram estudadas e mesmo reunidas em livro como Formação de discoteca e Recordações de Ismael Nery. ${ }^{2}$ A primeira apresenta o que Murilo publicou no suplemento "Letras e Artes", do jornal carioca A Manhã, entre 1946 e 1947; a segunda recolhe os artigos que saíram no jornal O Estado de S. Paulo e em "Letras e Artes" no decorrer de 1948. Ambas giram ao redor de temas relevantes na vida do poeta: a música clássica e as lembranças do amigo Ismael Nery.

Sem temer cair no exagero, o conjunto de 1937 poderia ser identificado como textos de militância católica. Não foram reunidos em livro, nem receberam muita atenção. ${ }^{3}$ Com certeza não por ser a religião um tema menor no universo muriliano;

${ }^{1}$ A relação completa dos artigos utilizados inclui também textos com o mesmo caráter da série de 1937, publicados em outros periódicos: Murilo Mendes, "Perfil do Catolicão", Dom Casmurro, n. 8, 10.7.1937; Idem, "O catolicismo e os integralistas", Dom Casmurro, n. 13, 5.8.1937; Idem, "Integralismo, mística desviada", Dom Casmurro, n.14, 12.8.1937; Idem, "Resposta aos integralistas", Dom Casmurro, n. 15, 19.8.1937; Idem, "Breton, Rimbaud e Baudelaire", Dom Casmurro, n. 16, 26.8.1937 [republicado em Letras Brasileiras, n. 18, 1944]; Idem, "Cordeiros entre lobos", Dom Casmurro, n. 17, 2.9.1937; Idem, "Prendam o Papa!", Dom Casmurro, n. 18, 9.9.1937; Idem, "A Comunhão dos Santos", Dom Casmurro, n. 19, 16.9.1937; Idem, "Poesia Católica", Dom Casmurro, n. 20, 23.9.1937; Idem, "Resistência da Poesia", Letras Brasileiras, n. 20, dez 1944; Idem, "O Eterno nas Letras Brasileiras Modernas", Lanterna Verde, n. 4, janeiro de 1936. Para o perfil do semanário Dom Casmurro, ver nota 7, adiante.

${ }^{2}$ Respectivamente: São Paulo, Edusp/Giordano Bruno/Edições Loyola, 1993; e São Paulo, Edusp/Giordano Bruno, 1996.

${ }^{3}$ Entre breves referências a alguns desses artigos feitas por diferentes críticos da obra de Murilo Mendes, o conjunto ganhou maior atenção de Raul Antelo. Cf. "Murilo, o Surrealismo e a Religião" disponível em: <http://www.cce.ufsc.br/ñelic/boletim8-9/raulantelo.htm>. Acesso em: 4 fev. 2011. 
pelo contrário, mesmo o leitor que apenas sobrevoasse sua obra teria, em algum momento, a impressão de estar diante de uma poesia em boa medida religiosa.

Ao lado disso, não foi ainda suficientemente ressaltada a configuração do grupo de intelectuais ao qual o poeta mineiro esteve ligado: escritores e artistas que orbitaram ao redor de núcleos de católicos cariocas com topografia definida - tanto por instituições como o Centro D. Vital, a igreja do Colégio Santo Inácio e o Mosteiro de São Bento, quanto pelo grupo de amigos que se reuniam no consultório do médico e poeta Jorge de Lima ou na casa de Aníbal Machado. É preciso lembrar ainda toda uma rede de divulgação de ideias católicas que se desenha nos esforços empreendidos para a inserção desses intelectuais na vida política do país ${ }^{4}$ ou mesmo na criação da editora católica Agir. ${ }^{5}$

O que se procura ressaltar é, em primeiro lugar, a intensa vida intelectual católica e carioca da qual fez parte Murilo Mendes, flagrada aqui na colaboração do poeta-jornalista com Dom Casmurro. Mas, ao mesmo tempo, não se pode deixar de considerar a existência do embate, presente nos jornais e revistas ${ }^{6}$ que reúnem intelectuais e escritores, pela autoria de ideias que garantiriam a linha de continuidade do modernismo ou a modernização do país, quando o modernismo paulista deixava de ser sua expressão maior. Assim, a tomada de posição incisiva de Murilo Mendes contra o Integralismo, presente em todos os artigos escritos para Dom Casmurro é, ao mesmo tempo, uma defesa do catolicismo enquanto doutrina e fé, e do catolicismo como única e verdadeira opção para um Brasil moderno. ${ }^{7}$

Pouco se escreveu sobre Murilo Mendes e o catolicismo, como também pouco se escreveu sobre o poeta mineiro enquanto intelectual participante da vida literária brasileira. ${ }^{8}$ Talvez isso seja devido à própria força de sua lírica, suficientemente

\footnotetext{
${ }^{4}$ Ver a respeito o pioneiro Antonio Carlos Villaça, O pensamento católico no Brasil (1975), Rio de Janeiro, Civilização Brasileira, 2006.

${ }^{5}$ O primeiro livro publicado pela Agir foi o de Gustavo Corção, A descoberta do outro, em 1944.

${ }^{6}$ Sobre a importância da imprensa católica e de seus intelectuais leigos no projeto de modernização do país, ver M. Gonçalves, "Uma reflexão sobre a intelectualidade católica", Revista de Sociologia e Política, n. 28, Curitiba, junho 2007, que também sintetiza as questões e debates em vigência nas atuais pesquisas.

${ }^{7}$ Tania de Luca vem estudando o universo das revistas e jornais literários no Brasil. Suas pesquisas abordam o período de 1916 a 1944 e entre os periódicos estudados está Dom Casmurro. Relata a pesquisadora que o primeiro número do jornal literário circulou em 13 de maio de 1937, mantendo-se ativo por quase dez anos. Foi fundado por Brício de Abreu, seu diretor, e Álvaro Moreyra, que ocupou o cargo de redator-chefe, assim como Moacir Deabreu, Marques Rebelo e Jorge Amado. Teve grande circulação. Entre seus colaboradores encontra-se Rubem Braga, Lúcio Rangel, Joel Silveira, entre outros. A partir de depoimento de Joel Silveira, que começou sua carreira no jornal, Murilo Mendes teria sido nome de destaque, "a estrela principal do Dom Casmurro", com seus ataques semanais aos integralistas. A série teria sido encerrada, segundo Silveira, pela constatação tanto dele como de Murilo Mendes de que o clima de censura instaurado pelo governo Vargas poderia vir a causar problemas. Sendo o centro de interesse maior dessa pesquisa o tratamento reservado pelas revistas à questão do intelectual na era Vargas, para o fim da colaboração de Murilo Mendes com Dom Casmurro Tania de Luca aventa a hipótese preliminar que se tratou de autocensura. Cf. Tania de Luca, Leituras, projetos e (re)vistas do Brasil 1916-1944, p.153-157 (no prelo).

${ }^{8}$ C. M. Rodrigues, na análise que faz da revista católica Ordem, apresenta do seguinte modo Murilo Mendes: "Poeta e escritor de renome e influência tanto no meio literário como político desde
} 
poderosa para se apresentar por si só; talvez os dezessete anos que o poeta passou longe do Brasil expliquem a lacuna na bibliografia muriliana: fisicamente ausente do país de 1957 até sua morte em 1975, sua participação na vida brasileira foi bruscamente interrompida, sua figura pública parcialmente esquecida. Embora haja tantos outros motivos que poderiam ser aventados, é muito plausível supor que a crítica terá tido dúvidas sobre como tratar um poeta ou intelectual católico, por mais esquisito que esse fosse, a partir dos parâmetros que definiram os signos da modernidade no início do século XX no Brasil. Ou dito de outro modo, num século em que predominou a ideia de suspeita (nos rastros deixados por Marx, Freud e Nietzsche e retrabalhados posteriormente por Foucault), como compreender o poeta religioso já que "crença significa essencialmente confiança"? ${ }^{9}$ Por último, o que seria um poeta católico brasileiro moderno?

Além dessas dificuldades de tipo filosófico, terá havido outras de caráter estético ou literário. Simpsom, por exemplo, ao criar sua antologia da poesia cristã francesa do século XX deparou com poetas que poderiam ser vistos como católicos mas nem por isso católicos do mesmo modo, sob o mesmo credo, optando por usar o cristã para tal poesia, acomodando assim no mesmo livro o anticlerical Charles Péguy e o vanguardista Max Jacob. De outro ponto de vista e em outro país, a tensão reaparece: Mário Faustino não hesitou em reservar o lugar de grandes experimentadores - e não de poetas religiosos experimentais - a Max Jacob e Pierre Reverdy. ${ }^{10}$

O assunto é espinhoso, os caminhos para trilhá-lo, escorregadios. Murilo Mendes possui significativa produção como poeta católico, embora não seja tarefa simples qualificar seu catolicismo e sua poesia religiosa; é considerado um importante intelectual católico laico nas crônicas ou história das ideias católicas brasileiras e de seus intelectuais e escritores, mas a história desse grupo ainda não está escrita por inteiro. Por essas e outras razões, se começa aqui pelas bordas: pelos textos que Murilo Mendes escreveu para jornais sobre catolicismo e sobre poesia católica, dando destaque para a presença entre nós e em Murilo, tanto do pensamento como da poesia católica franceses das primeiras décadas do século XX.

Voltando à série de artigos mencionada, Murilo Mendes abre a sequência traçando o que se poderia chamar como o identikit do católico mais banal, conservador, obtuso, nada espiritualizado. "O perfil do catolicão", título do artigo de 10 de julho

os anos de 1920". Na perspectiva dos estudos literários brasileiros, tal descrição de perfil levaria muito mais a se pensar em Carlos Drummond de Andrade ou Mário de Andrade. Parece, assim, que é mais fácil ao historiador, na sua intimidade com a história brasileira, reconhecer o poeta Murilo Mendes também como homem público.

${ }_{9}^{9}$ Pablo Simpson (org. e trad.), O rumor dos cortejos. Antologia da poesia cristã francesa do século XX, São Paulo, FAP-Unifesp, 2012. A antologia foi fonte importante para este artigo, em particular a Apresentação, na qual Simpson procura estabelecer alguns parâmetros estéticos para a linhagem poética da poesia cristã francesa do século XX. A citação é do filósofo francês e católico Henri Bergson.

${ }^{10}$ Mário Faustino, Artesanato em poesia, org. M. E. Boaventura, São Paulo, Cia. das Letras, 2004. 
de 1937, é um retrato no qual a ironia, o humor sem piedade e a pedagogia evangelizadora dividem o mesmo espaço, espaço esse caprichosamente delimitado por uma linha em branco que separa os "assuntos", dando ao texto um formato de pequenos blocos. ${ }^{11}$ No final, o catolicão surge em corpo inteiro (já que de alma tem-se muito pouco): com mais de trinta anos - a generosidade, idealismo e impulsividade dos mais jovens os impedem de pertencer à categoria; trata-se de um fariseu acabado; totalmente alienado e incapaz de formular uma argumentação qualquer; não conhece a Bíblia ("é coisa de protestante") e muito menos a liturgia, desconfia do culto que lhe parece algo a ser superado com o tempo; para o catolicão, "Deus é cafiaspirina", se lembrando dele somente nas horas de aperto; moralmente é um desastre: todas as questões sociais são, na verdade, simplesmente caso de polícia, sejam elas a propriedade privada, a sexualidade ou ainda a usura; tem uma concepção estreitíssima de nacionalismo e caracteriza-se pelo péssimo gosto e falta de ousadia em arte e literatura. Está claro que ele próprio se coloca como a antítese do catolicão.

A cada um desses tópicos que compõem, primeiramente, uma peça satírica, um divertido e conhecido perfil do católico "homem comum" (não poupando sequer certos padres), Murilo acrescenta a voz de uma Igreja autorizada e moder$n a^{12}$ que se anuncia pelas encíclicas papais - a de Bento XV e Leão XIII são citadas - ou através de argumentos de uma Igreja superior, culta, aggiornata com o mundo, com as ideias e as artes em geral, o que acaba por enfatizar a boçalidade daquele catolicismo primário.

O catolicão possui um senso tão agudo da propriedade, que acredita ser a burrice propriedade dele só. Ninguém mais tem o direito de ser burro. Os catolicões tiraram patente. Um indício seguro para se reconhecer o catolicão: ele tem um inexcedível mau gosto em matéria de arte e de literatura. O catolicão prefere tudo o que é insípido, incolor, aguado. Repugnam-lhes os alimentos fortes, os tons violentos, precisos. [...]. Não sei se foi a Casa Sucena que determinou o catolicão, ou foi o catolicão que determinou a Casa Sucena. Só sei que a Casa Sucena é um fenômeno alarmante [...]. O catolicão não aborda os livros de Dom Columba ou de Dom Volnier - mas sabe de cor páginas inteiras de "Uma rosa desfolhada" ou do "Manualzinho da perfeita piedade (Que encanto, que delicadeza, que mimo!...). [...] Deus me perdoe: mas eu perderia o ânimo de fazer uma oração diante de uma dessas feias imagens (ou bonitinha demais), fabricadas em série, que inundam as prateleiras de todas as nossas casas sucenas e igrejas. A vida terrestre da segunda pessoa da santíssima Trindade, Jesus Cristo, o Filho de Deus encarnado é uma formidável obra de arte, do princípio ao fim. Uma transfiguração contínua. As oferendas que the entregamos devem ser produto de uma meditação profunda de uma intensa vida espiritual - e suas realizações orientadas de acordo com os princípios evangélicos e com o espirito eterno da Igreja. (grifo meu)

${ }^{11}$ Os traços respondem provavelmente à necessidade de estabelecer certa clareza e unidade à argumentação e podem ter um parentesco com as famosas bolinhas pretas que marcaram sua presença nos poemas murilianos.

${ }^{12}$ Para o quadro mais amplo do movimento de modernização da Igreja Católica na Europa e no Brasil, ver M. T. da Costa, "Los tres mosqueteros. Una reflexión sobre la militancia católica lega en el Brasil contemporâneo", Prismas, Revista de Historia Intelectual, n. 11, p. 55-67, 2007. 
A linguagem fluente, os comentários agudos, o humor corrosivo que estão no divertido retrato do catolicão desaparecem no trecho grifado, quando o tom se eleva a grandes alturas. O contraste entre a linguagem da crítica e a da exegese é sugestivo: faz lembrar, por exemplo, que há poemas de Murilo onde a voz lírica assume proporções proféticas, soando do alto do mundo, e há outros em que o eu lírico é tocado pelo humor mais dessacralizante. Essa dicotomia já foi tratada como oposição muriliana ou luta poética entre a ordem e a desordem, ${ }^{13}$ entre o tempo e a eternidade, como sabemos; o que esses artigos parecem acrescentar é que a voz lírica profética ensaia os primeiros passos em alguns momentos da prosa jornalística, se transformando em explícita mensagem de convencimento religioso, ou seja, em militância católica.

Nessa mistura de vozes, uma direta, saindo em defesa de um ponto de vista moral e religioso, e outra voz, elaboradíssima, que compõe os poemas sofisticados, entrevê-se Murilo Mendes como intelectual católico, na década de 1930, envolvido por um momento muito expressivo na história do catolicismo no Brasil: o da sua modernização que se dá sob os influxos do pensamento católico francês - Jacques Maritain, George Bernanos, Emanuel Mounier, Teillard de Chardin, Yves-Marie Congar entre outros - que chega à América Latina trazendo ares de renovação e que terá em Alceu de Amoroso Lima a figura proeminente dessa nova fase, nome reverenciado por Murilo ao longo de cerca de cinquenta anos de amizade fraternal. ${ }^{14}$

Assim, embora as encíclicas papais sejam continuamente citadas por Murilo Mendes como a lei a ser obedecida, o pensamento filosófico que motiva e conduz os embates brasileiros sobre catolicismo e sociedade não vem de Roma; e não vem de Roma nem mesmo a inspiração para o intelectual laico que se dispõe a combater a Igreja tradicional.

A fonte para essa visão moderna estava em Paris. Tanto do ponto de vista institucional como do indivíduo e sua fé, de 1865 a 1937, a França viveu um longo período de grande indiferença religiosa. No âmago dessa grande crise foram escritas inúmeras cartas pastorais as quais procuram combater a influência do ensino laico, tornado lei em 1905, tentando suavizar a importância das novas ciências históricas; são criadas várias revistas especialmente para discussão e divulgação

${ }^{13}$ É mais do que uma curiosidade o fato de o título da importante revista católica brasileira, fundada em 1921 pelo intelectual Jackson de Figueiredo, ter sido A Ordem. Ao se referir ao período, Villaça falará de "tríplice revolução", aludindo também à realização da Semana de Arte Moderna em São Paulo e à criação do Partido Comunista, em 1922. Ver Villaça, O pensamento católico no Brasil, op. cit., p. 170. A coincidência, sem dúvida, tem um forte valor simbólico: exprime muito bem a situação dos "intelectuais na encruzilhada", título do livro organizado por F. A. Barbosa, reunindo a correspondência de Alceu de Amoroso Lima e António Alcântara Machado (1927-1933) (Rio de Janeiro, Academia Brasileira de Letras, 2001).

${ }^{14}$ Ver M. T. da Costa, Um itinerário no século. Mudança, disciplina e ação em Alceu de Amoroso Lima, Rio de Janeiro, Editora PUC Rio, Loyola, 2006, p.33-34. 
das ideias católicas. ${ }^{15}$ As conversões em série - Claudel em 1886, Huysmans em 1895, Leon Bloy em 1897, Paul Bourget em 1899 - expõem-se na forma da literatura pelas narrativas de convertidos, relatos predominantemente autobiográficos, emocionados e de grande impacto que testemunham, num início de século quase descrente, a possibilidade de uma saída espiritual para aquele persistente sentimento de decadência tão conhecido e generalizados entre intelectuais no Velho Mundo. ${ }^{16}$

Os relatos de conversão são justamente o que falta à literatura brasileira afirma Villaça no seu O pensamento católico no Brasil. A lista de convertidos também não é muito grande - Murilo Mendes é lembrado "como o último dos grandes intelectuais [brasileiros] convertidos". ${ }^{17}$

A literatura brasileira é pobre de documentos dessa natureza. Dos nossos grandes convertidos intelectuais - Jackson de Figueiredo, Alceu de Amoroso Lima, Hamilton Nogueira, Joaquim Nabuco, Júlio Maria, Felício dos Santos, Gustavo Corção, Paulo Setúbal, Murilo Mendes, Jorge de Lima, Cornélio Pena -, só três nos escreveram o relato, a história da sua conversão: Joaquim Nabuco, em Mysterium Fidei, 1893, Paulo Setúbal, em Confiteor, 1935, e Gustavo Corção, em A descoberta do outro, $1944 .{ }^{18}$

A escassez de testemunhos não parecerá tão estranha ou surpreendente se, seguindo de perto o próprio Villaça, considerarmos que, ao contrário da França do século XIX, entre nós, "havia o hábito, o costume religioso. Não havia o problema religioso". ${ }^{19}$

Murilo Mendes nos seus artigos e ensaios de militância católica - e o retrato do catolicão é um desses momentos - participa de um embate contra essa ignorância religiosa, bem conhecida e arraigada na elite brasileira, levado por inúmeros intelectuais e religiosos católicos nos anos 1920 e 1930 no Brasil, em luta contra a religião de hábito, por uma sofisticação do catolicismo como pensamento religioso e político, capaz de estabelecer novas bases, institucionais e doutrinárias, para que a Igreja Católica se apresentasse como uma força moderna de integração da sociedade. Esse debate, contudo, terá sempre como adversários religiosos aferrados à velha igreja tradicional, "triunfalista, tridentina, em luta aberta com o mundo e a modernidade", ${ }^{20}$ mas não somente esses, como se pode ler nos três artigos seguintes para o Dom Casmurro, publicados respectivamente em 5, 12 e 19 de agosto, intitulados "O catolicismo e os integralistas", "Integralismo, mística desviada" e "Resposta aos Integralistas".

15 "É nesse período que surgem revistas literárias de inclinação religiosa, como Vigile, projeto de Jacques Maritain, Les cahiers de l'Amitié de France, de Robert Vallery-Radot e François Mauriac, ou teológico-filosóficas, como L'Esprit, que não se declarava católica, além de Catholicisme Social, Sept, Terre nouvelle, Le vie intellectuelle [...]". Simpson, O rumor dos cortejos, op. cit., p. 9.

${ }^{16}$ Idem, ibidem, p. 10

${ }^{17}$ Villaça, O pensamento católico no Brasil, op. cit., p. 115.

${ }^{18}$ Idem, ibidem, p. 108.

${ }^{19}$ Idem, ibidem, p. 50.

${ }^{20}$ Costa, Um itinerário no século, op. cit., p. 29. 
Dessa vez, não é ignorância da liturgia, da doutrina e do pensamento católico o que desencadeia os ataques do poeta, mas a politização e partidarização do catolicismo propostas por conservadores integralistas em 1937.

Está-se desenvolvendo em nossos meios católicos uma mentalidade errada em relação ao problema catolicismo-integralismo. Que o integralismo, como doutrina, não se oponha em seus princípios fundamentais, à doutrina, estou de acordo; mas que os católicos sejam obrigados a entrar para o integralismo afim de "salvarem" a Igreja, a religião católica e o Brasil, aí é que começa a briga. ${ }^{21}$

A razão mais forte para essa condenação vem da confiança na vitória da Igreja como força política, capaz de vencer comunismo e fascismo e se impor como pensamento moderno.

Vingança! Justiça! Ódio aos comunistas! Matemos os judeus! Gritam os sigmáticos. Amor! Perdão! Clemência! Amemos nossos adversários! Preguemos-lhes a beleza e a universalidade do Evangelho! Adotemos o grego, o bárbaro, o russo, o judeu, o operário escravizado e lhes mostremos a superioridade da doutrina de Cristo, encarnada na Igreja - devem responder os católicos. Porque assim como os primeiros cristãos absorveram dialeticamente o helenismo e o judaísmo, assim nós, católicos, devemos absorver o fascismo e o comunismo, incorporando-os na corrente universal da Redenção que arrasta, consciente ou inconscientemente, os homens para o Cristo [...].22

Alguns dos argumentos de Murilo retornam em nova formulação num importante texto publicado em 26 de agosto, intitulado "Breton, Rimbaud e Baudelaire", no qual aborda com a costumeira convicção e retórica o universo da poesia francesa moderna nas suas relações com o catolicismo: Rimbaud e Baudelaire são lidos a partir de uma perspectiva crítica e interpretativa de modo a inseri-los na linhagem da poesia religiosa e católica.

O ponto de partida é o livro de André Breton Position politique du surréalisme publicado em 1935. O poeta mineiro lê e discorda profundamente da interpretação de Breton ao defender a poesia de Baudelaire e Rimbaud como a de "revoltados e inconformistas", procurando assim retirá-la das mãos da burguesia que segundo o grande surrealista esperam torná-la poesia católica. O ataque de Murilo é contundente: afirma que, em primeiro lugar, a burguesia não tem o menor interesse em poesia, estando muito atarefada na vida prática com outros afazeres, para em seguida demonstrar em sua interpretação como os poetas franceses eram sim positivamente católicos.

É significativo que logo no início de sua argumentação comente as dúvidas que pairam sobre a conversão de Rimbaud:

Quanto ao caso de Rimbaud, admito reservas e dúvidas. Apesar do testemunho de sua irmã Isabelle, segundo o qual o vidente de "Les Illuminations" teria se confessado e comungado na

${ }^{21}$ Cf. Murilo Mendes, "O catolicismo e os integralistas", op. cit., ver nota 1.

${ }^{22}$ Cf. Murilo Mendes, "Resposta aos integralistas", op. cit., ver nota 1. 
hora da morte - e que necessidade teria essa pessoa de mentir em tão grave assunto? - os céticos têm direito de duvidar, achando que na semi-consciência da agonia tudo é possível.

Mas o fato é que a obra de Rimbaud está toda impregnada de um profundo sentimento cristão. $^{23}$

Um ponto de partida como esse nos indica a importância assumida pelo testemunho oral ou da narrativa da conversão. Talvez para compensar a escassez dessas narrativas no Brasil e dada a importância que assumem nessa verdadeira batalha campal dos católicos, a Livraria Agir Editora publicou em 1953-1954, em dois volumes, a tradução do livro francês Convertidos do século XX, apresentado por F. Lelotte, reunindo relatos sobre a conversão de grandes intelectuais, em geral franceses, como Charles Péguy, Paul Claudel, Henri Bergson, Julien Green, Léon Bloy, Giovanni Papini, Jacques e Raïssa Maritain. São textos hagiográficos. Em quase todos se revela o descompasso entre a urgência de se encontrar - e divulgar - a cena da conversão e a inexistência da cena em não poucas biografias de intelectuais convertidos. O início do artigo de Murilo ilustra muito bem esse clima e essa circunstância.

A narrativa da conversão, portanto, assume o papel de uma espécie de prova de evidência com força de convencimento. E mais, são relatos de autoridade, já que os laicos convertidos não são nunca homens comuns, são figuras de destaque, proeminentes na vida social de seus tempos. Murilo a esse respeito lembra que foi "Une saison en enfer que determinou a conversão de Paul Claudel". Mas a análise do famoso livro de Rimbaud não para por aí. Dirá ainda:

Nesse livro sombriamente, desesperadamente cristão [...] - não desse cristianismo adocicado de Coppés ou Francis Jammes, mas do cristianismo catastrófico de certos místicos da Idade Média, que força religiosa, que intuição do martírio e do sacrifício. [...] Quando diz que "l'existence est ailleurs" e "que nous ne sommes pas au monde", transcreve - talvez inconscientemente - palavras de despedida do Cristo aos apóstolos, no Evangelho de São João - palavras que Breton naturalmente desconhece..."J'ai reçu au coeur le coup de la grâce!". E a sentença famosa - "changer la vie" - é a mesma que S. Paulo aplica ao homem velho - o homem formalista, o fariseu, o rotineiro - para se revestir do homem novo, que enxerga todas as coisas à luz do Cristo, e ajuda à transfiguração do mundo. ${ }^{24}$

Enquanto Murilo admite que sobre a conversão de Rimbaud pudesse pairar alguma dúvida, Baudelaire é apresentado como "um poeta informado de catolicismo até a medula". E continua:

Evidentemente não era o que se chama hoje, em linguagem miúda, "praticante", mesmo porque viveu numa época de grande decadência religiosa. E o espetáculo de um clero de mãos dadas com governos violentos e reacionários deveria esfriar bastante um espírito sincero e independente como o seu. Mas um homem que tinha um conceito gravíssimo de pecado, de julgamento e de inferno como o iluminado de "Les fleurs du Mal", um homem formado - segundo

${ }^{23}$ Cf. Murilo Mendes, "Breton, Rimbaud e Baudelaire", op. cit., ver nota 1.

${ }^{24}$ Idem, ibidem. 
deixou escrito por Joseph de Maistre e Poe, desautoriza pela sua obra a opinião de Breton. Baudelaire é um dos raríssimos homens que, em crítica de música e de pintura, tratando de problemas puramente estéticos, falam do pecado original, mencionam o Espírito Santo, o Verbo Encarnado, a superioridade da doutrina católica [...].

No seu livro "Mon coeur mis à nu" - livro que respira catolicismo em todas as páginas declara que "a verdadeira civilização não consiste no gás, nem na máquina a vapor nem nas mesas giratórias do espiritismo e sim na diminuição dos vestígios do pecado original. A meu ver só um homem integralmente possuído pelo espírito católico poderia ter escrito uma tal frase. ${ }^{25}$

Se o tom continua sendo o da defesa do catolicismo como doutrina e como instituição enquanto força constitutiva da modernidade, Murilo indica com muita clareza o que no catolicismo lhe interessa mais de perto, ao tratar de poesia e de poetas que conhece muito bem e que ama: de Baudelaire ressalta o "conceito gravíssimo de pecado, de julgamento e de inferno", do mesmo modo que em Rimbaud a presença "do cristianismo catastrófico de certos místicos da Idade Média", sublinhando nele a "força religiosa", a "intuição do martírio e do sacrifício".

O catolicismo muriliano privilegia as vertentes martirológicas, noções como a de pecado, sofrimento, dor constituindo um ponto de vista, expresso de modo lírico ou não, ativo tanto na sua poética como nos artigos de jornal, definindo, obviamente, resultados totalmente diversos nas formas dos textos. Num texto de muitos anos depois, escrito em francês, em 1961 e intitulado Bernanos: instantané, Murilo Mendes comporá, ao lado do retrato do amigo, um seu próprio autorretrato, reiterando alguns elementos desse "conhecimento do mal".

Cette aptitude permanente à déranger l'ordre conventionnel, les thémes politiques, esthétiques et religiueux qui lui étaient proposées [...] il les tenait de ses anciennes reserves. Je veux dire qu'il était conscient de son enfance, qu'il la portrait avec lui. [...] L'enfant est, en effet, l'être subversif par excellence; le plus proche, selon Baudelaire, du péche originel, ce que implique de sa part une mystérieuse connaissance du mal. ${ }^{26}$

Em Discípulos de Emaús, livro publicado em 1945, encontra-se o mesmo tema: A consciência viva do pecado é um elemento dinâmico de ação espiritual, e de energia. ${ }^{27}$

Para esses escritores católicos da primeira metade do século XX, a figura do pecado original assume proporções grandiosas e é central na formulação de seu pensamento. ${ }^{28}$ Antirousseaunianos por natureza, é pelo pecado original, pelo

${ }^{25}$ Idem, ibidem.

${ }^{26}$ George Bernanos, escritor francês, viveu no Brasil, principalmente em Minas Gerais, durante a Segunda Guerra Mundial, tornando-se personalidade de destaque no meio católico brasileiro. Ver "Dossiê: Bernanos e o Brasil", Revista Literatura e Sociedade, n. 9, p. 308-362, 2006. Murilo Mendes, Poesia completa e prosa, org. L. S. Picchio, Rio de Janeiro, Nova Aguilar, 1995, p. 1572.

${ }^{27}$ Murilo Mendes, Poesia completa e prosa, op. cit., p. 820.

${ }^{28} \mathrm{O}$ crítico francês Antoine Compagnon reconhece nesse tema uma das características daquilo que procura caracterizar como a antimodernidade de importantes autores franceses, entendendo antimodernidade não como o "neoclassicismo, o academicismo, o conservadorismo ou o tradicionalismo, mas como a resistência e ambivalência das verdades modernas", ou seja, vistos neste século XXI, seriam os antimodernos os verdadeiros modernos. Os seis temas ou figuras da antimo- 
conhecimento do mal, que deixam de acreditar nas revoluções, pondo em dúvida as conquistas alcançadas - o vapor, a máquina etc. - pelo progresso do homem. Em paralelo e obviamente, será de modo exclusivo a relação do indivíduo com a ordem do sagrado o que poderá proporcionar sua redenção. A interpretação de Murilo assume essas vestes, tecidas num contexto (e pelo papel assumido de intelectual católico militante), não nos esqueçamos, de enfrentamento das questões políticas da época, em particular no que diz respeito ao pertencimento ou não dos intelectuais (e poetas) católicos, segundo a visão de Murilo, a partidos e doutrinas como o comunismo e ao integralismo brasileiro.

Parece-me que André Breton conhece mal seu Baudelaire. O mesmo acontecerá talvez a seus colegas de credo político. O entusiasmo de muitos talvez esfriasse um pouco se meditassem certos textos. Ouviram dizer que Baudelaire tomou parte nas barricadas de 1848, e deliram; mas saberão eles que dessa mesma revolução escreveu muito mais tarde: "1848 ne fut amusant que parce que chacun y faisant des utopies comme des châteaux en Espagne". [...]

Além disto Baudelaire estava longe de ser um "progressista". Eis a sentença que ele legou aos atuais adoradores da massa, aos incuráveis otimistas da nossa época coletivista: "Il ne peut y avoir de progrès (vrai, c'est-à dire moral) que dans l'individu et par l'individu lui-même".

A questão se resume no seguinte: Breton desconhece inteiramente o catolicismo, ou confunde com os catolicões. Ele julga que essa doutrina só pode abrigar os bem-pensantes, os carolas, os conformados com a mediocridade, e os fanáticos da ordem policial. Entretanto, o espírito católico é mais revolucionário e explosivo que o próprio marxismo. Enquanto o marxismo espera a destruição de uma classe, a transferência de seus bens para outra, e a instalação de um confortável paraíso na terra, o catolicismo espera a destruição do universo inteiro pelo fogo do Espírito Santo. Não ficará pedra sobre pedra!

No mesmo livro "Position politique du surréalisme", Breton afirma que o artista deve buscar suas inspirações no tesouro coletivo, na alma popular, devido á solidariedade que liga os homens entre si. Ao declarar isto, transcreveu um dos princípios básicos do grande dogma da Comunhão dos Santos...29

A frase "o espírito católico é mais revolucionário e explosivo que o próprio marxismo" traz à baila, junto à certeza de uma potente força política no catolicismo, um importante tema de reflexão sobre a poesia no século XX, a partir das

dernidade - a contrarrevolução, o anti-iluminismo, o pessimismo, o pecado original, o sublime e a vituperação - que já constituíram, em estudos tradicionais e bem conhecidos, a expressão do conservadorismo filosófico, literário e político da República Francesa das Letras, ganham novo significado, numa operação crítica muito rica mas que não deixa de soar como uma espécie de autossalvamento da modernidade, executado por Compagnon. Embora aparentemente seja possível associar o Murilo polemicista a essa linhagem, há que ressaltar que são o Iluminismo e a Revolução Francesa as referências mais fortes para esse quadro crítico. No Brasil não tivemos nada parecido, o que dificulta a aproximação. Ver Antoine Compagnon, Les antimodernes de Joseph de Maistre à Roland Barthes, Paris, Gallimard, 2005.

${ }^{29}$ Em "Breton, Rimbaud e Baudelaire" (op. cit., ver notal) Murilo Mendes escreverá em 1967, em francês, uma homenagem ao surrealista, na qual não há alguma referência à crítica anterior, talvez somente recuperável para ele através de um esforço de memória ou então simplesmente delegada à memória. Ver Murilo Mendes, Poesia completa e prosa, op. cit., p. 1591-1593. 
relações entre lírica, religião e política que impregna também a reflexão de Murilo tanto sobre poéticas como sobre os temas da contemporaneidade e nos conduz a um universo visto em paralelo, ainda católico, europeu e afrancesado: o da crítica e da poesia católicas italianas na primeira metade do século XX. Três desses críticos - poetas eles também - escreveram sobre a poesia de Murilo Mendes: Oreste Macrì, Mario Luzi e Ruggero Jacobbi. ${ }^{30}$

Imersos na mesma inspiração francesa, mas vivida a partir da própria tradução cultural e literária, a poesia que será denominada hermética (não pelos seus teóri$\cos$ - Bo e Macrì entre os principais - que não aprovam tal denominação) projeta o mesmo espírito europeu - identificado com o catolicismo e com a poesia lírica moderna - como signo e esperança para a instalação da única civilização possível para esses intelectuais.

É o que diz Oreste Macrì em livro que homenageia o grande crítico e teórico, católico, da poesia hermética italiana, Carlo Bo. "[...] naqueles anos trinta a politique de l'esprit européia era literária". ${ }^{31}$

Ou ainda, mais explicitamente

A literatura francesa, como se sabe, foi o centro irradiador, europeu, planetário de todo e qualquer interesse da mente e do espírito, lugar histórico e contemporâneo quase sagrado, de liberdade e múltipla experiência, fundidos em um nexo indivisível artístico-literário-ético-religioso-social no esplendor agônico daquela civilização na sua última florescência. ${ }^{32}$

\section{Ainda}

Me referi anteriormente ao nosso europeísmo sub specie "literária" e ao sentido de tal literatura [...] Bo produziu seus primeiros e mais extensos estudos, começando por Claudel. Espírito europeu, não "cultura", termo confuso e equivocado, estranho a nossa mentalidade enquanto categoria e militância [...]. ${ }^{33}$ A nossa constelação de capitais do espírito europeu Atena-Florença ${ }^{34}$-Paris prescindia das nacionalidades particulares, mas não de modo polêmico, que fique bem entendido. Nossos poetas, amadurecidos pela nossa literatura crítica, dita (não por nós) hermética, se refaziam aos ícones primevos, populares e familiares, solidários e presentes na imagem de uma Europa ácrona, comum e fraternal. ${ }^{35}$

\footnotetext{
${ }^{30}$ Ver Maria Betânia Amoroso, Murilo Mendes. O poeta brasileiro de Roma: história de uma leitura. 2009, tese (livre-docência), Universidade Estadual de Campinas, Campinas, 2009.

${ }^{31}$ G. Tabanelli, Carlo Bo. Il tempo dell'ermetismo, Milano, Garzanti, 2006, p. 65 [tradução minha].

${ }^{32}$ Idem, ibidem, p. 66 [trad. minha].

${ }^{33}$ Em artigo anterior tratei da polêmica ocorrida nos anos 1930 entre dois importantes intelectuais italianos, Carlo Bo e Elio Vittorini, ao redor de uma frase do primeiro cujo sentido é aqui retomada por Macrì: "Cristo não é cultura", significando que a noção de cultura não alcança o valor espiritualizado e universal que a figura de Cristo encarna para esses católicos; Vittorini, próximo às ideias marxistas, ao invés, poderia, no máximo, admitir a presença do cristianismo como uma fonte da cultura ocidental. Ver Maria Betânia Amoroso, "Passeio na biblioteca de Murilo Mendes", Remate de Males, Campinas, n. 21, p. 123-147, 2001.

${ }^{34} \mathrm{O}$ grupo de Macrì e Bo era sediado em Florença e lá, entre universidade, revistas literárias, traduções, antologias e grande produção ensaística constituiu-se um primeiro núcleo ativo de literatura comparada na Itália, animado por esse espírito europeu que o crítico descreve entusiasticamente.

${ }^{35}$ Tabanelli, Carlo Bo. Il tempo dell'ermetismo, op. cit., p. 67.
} 
A passagem do Brasil para a França e depois para a Itália, aparentemente abrupta, é suavizada quando lembramos que também para esses italianos a referência máxima está na França, e nos poetas como Reverdy e Claudel. Também para eles o espírito católico ou cristão se identifica, encarna totalmente o espírito da Europa, esperando que os homens da cultura (alta, altíssima) a disseminem. A França é esse espírito para Murilo Mendes. Em um artigo publicado em dezembro de 1944, quase a um ano do final da guerra, Murilo Mendes resenha uma antologia de poetas franceses contemporâneos. Não são os poetas a real tônica do artigo. Nele expõe muito mais sua preocupação e atenção para com a guerra, em particular com a articulação do movimento da Resistência. Na verdade, essa nova poesia e a organização do movimento, deixam-no, em 1944, totalmente confiante na hegemonia cultural da França no Ocidente. ${ }^{36}$

Diante da capitulação militar da França em 1940, não faltou entre nós quem assinasse o atestado de óbito da grande nação francesa. Mais de um escritor veio para a rua declarando com toda calma que a França estava liquidada para sempre: seria de agora em diante uma lembrança de museu.

Alisto-me entre os que pensaram e afirmaram o contrário. Não seria essa a primeira derrota sofrida pelo país de Racine. Não seria a primeira vez da ocupação de sua capital. A França ressurgiria mais cedo ou mais tarde, voltando a ocupar o lugar que lhe compete no mundo.

\section{Depois de ter tecido elogios à formação da Resistência, acrescenta:}

Ainda há poucos dias, evocávamos, o escritor e Professor Michel Simon, a França dos últimos tempos. Na mesma época - reunidos - como numa segunda Renascença, numa segunda Plêiade - os nomes de Bergson, Règny, Barrès, Claudel, Gide, Valéry e tantos outros. Os "Cahiers de La Quinzaine". O movimento unanimista. O movimento do apostolado social. A série de espantosos debates de consciência e de opinião do caso Dreyfus. O significado universal da Escola de Paris, síntese de todas as correntes artísticas da nossa época. As conversações de Pontigny. O espetáculo raríssimo - só presenciado antes, talvez na Grécia antiga - de um escritor da importância de André Gide, comparecendo perante um tribunal de adversários. Um governo de frente popular recebendo a colaboração da Igreja. E tantos outros sinais marcantes de um corpo social crescendo para uma realização histórica sob o signo de um ideal altamente civilizador. ${ }^{37}$

No artigo, que de modo disperso vai reunindo flashes dessa França cultuada, os encontros na antiga abadia cisterciense de Pontigny, do século XII, descrevem a vida intelectual desejada (e idealizada) pelo poeta, distante do mundo rumoroso e em frangalhos das guerras europeias e distante, muito distante da vida cultural brasileira.

${ }^{36}$ Cf. Murilo Mendes, "Resistência da Poesia", op. cit. ver nota 1. Notar o contraste entre esse texto de 1944 e um dos mais conhecidos poema do poeta, inclusive na Itália, que tem como título uma data 1941: Adeus ilustre Europa / Os poemas de Donne, as sonatas de Scarlatt i / Agitam os braços pedindo socorro: / Chegam os bárbaros de motocicleta, / Matando as fontes em que todos nós bebemos. Somos agora homens subalternos, / Andamos de muletas / Preparadas pelos nossos pais. / O ar puro e a inocência / Estão mais recuados do que os deuses gregos. Somos o pó do pó, / Fantasmas gerados pelos próprios filhos. / Nunca mais voltará a fé aos nossos corações, / Adeus ilustre Europa. Murilo Mendes. Poesia completa e prosa, op. cit., p. 348-9.

${ }^{37}$ Cf. Murilo Mendes, "Resistência da Poesia", op. cit. ver nota 1. 
Num ambiente de verdadeira espiritualidade [...] reuniam-se todos os anos algumas dezenas de homens para discutir problemas intelectuais de transcendente interesse. Reinavam sempre a cordialidade e a serenidade, mesmo entre os que sustentavam opiniões opostas; sem que ninguém jamais elevasse o tom da voz. Talvez que a atmosfera do convento secular influísse sobre o espírito dos presentes, pois quase todos empregavam um vocabulário inspirado em termos monásticos, e muitos deles manifestavam com franqueza a nostalgia de uma Regra, de uma Ordem. Notava-se uma preocupação espontânea de disciplina dentro da liberdade. Havia número de danças e canto. O próprio Gide interpretava Chopin ao piano, Jean Schlumberger particularmente dotado para a dicção, dizia versos de Baudelaire e de Claudel. Uma vez uma filha de Tolstoi veio dançar. Eram homens de boa vontade que davam um exemplo, mostrando o caminho da civilização. Se não foram ouvidos e seguidos, a culpa não terá sido deles, mas de outros homens que desconhecem o valor da poesia. Pontigny é um grande marco cultural. Eis aí um convento ao meu gosto... (grifo meu) ${ }^{38}$

Há muita semelhança na confiança que Oreste Macrì e Murilo Mendes em uma possível regeneração do mundo, a partir dos pressupostos católicos e da poesia como seu recurso mais completo, o que parece ser, em síntese, o sentido maior do conjunto de artigos murilianos ao longo de 1937 principalmente.

Em 9 de setembro, o poeta volta a fazer denúncias sobre as atitudes da parcela conservadora dos católicos (sempre intelectuais laicos e religiosos atuantes) e da imprensa brasileira ao redor das atitudes de Jacques Maritain a respeito do fascismo e da guerra civil espanhola.

A confusão ultimamente aumentou [...] em torno da atitude assumida por Maritain e outros escritores católicos franceses diante da revolução espanhola. Nos seus últimos números, o jornal "O Povo", simpático ao integralismo, tem a audácia de expor o retrato de Maritain ilustrando violentos artigos, apontando-o como "traidor da Igreja" e "agente do Komintern. [...] Se há um homem que, pela sua vida exemplar, quase monástica, toda dedicada ao estudo e exegese da doutrina de Santo Tomaz de Aquino, merece o respeito e a consideração de todos, esse é Maritain. Pela sua autoridade e serenidade de filósofo cristão, rigorosamente fiel à disciplina e obediente às diretrizes da Igreja. Maritain está realmente fora e acima dos partidos políticos, sendo suas opiniões isentas de ódio, de parcialidade, e independentes de interesses subalternos. ${ }^{39}$

À defesa de Maritain, segue a sua própria, já que o jornal condenará Murilo Mendes como um desses maritanistas.

Como fui também citado pelo referido jornal "O Povo", venho declarar mais uma vez que considero a doutrina comunista incompatível com a doutrina católica; que no caso de ser aplicada, aumentaria o mal-estar existente no mundo; que a depositária da verdade total é a Igreja Católica Apostólica Romana, cuja orientação, pela voz esclarecida e inspirada do Sumo Pontífice, procuro seguir na medida das minhas pobres forças; e que a Igreja está acima e independente de todos os fascismos, comunismos e outros ismos deste mundo porquanto está apoiada no amor e na fé em Jesus Cristo, isto é, no ETERNO. ${ }^{40}$

\footnotetext{
${ }^{38}$ Idem, ibidem.

${ }^{39}$ Cf. Murilo Mendes, "Prendam o Papa!", op. cit., ver nota 1.

${ }^{40}$ Idem, ibidem.
} 
Num verdadeiro crescendo, Murilo Mendes caminha para o encerramento da polêmica: "Poesia Católica" é publicado em 23 de setembro e, por assim dizer, fecha o ciclo de seus artigos especiais para Dom Casmurro.

Iniciando a polêmica pelo retrato do católico comum brasileiro, segue comentando a igreja tradicional - e "burguesa" como o poeta dirá -, criticando duramente a aproximação entre católicos e integralistas. Sem deixar de anunciar quais são seus modelos, Murilo escreve o último artigo que, lido em retrospectiva, parece ser o ápice da polêmica, o ponto final de uma argumentação construída artigo após artigo. O título é a melhor síntese: "Poesia católica".

Os primeiros versos de Apollinaire - "chefe do mais importante movimento de arte e poesia moderna" - do poema Zone ${ }^{41}$ abrem o artigo em epígrafe e as relações entre modernidade e catolicismo são aqui, mais do que em outros textos, centrais para a compreensão da Igreja (e da poesia) que anima o poeta. Apollinaire é então apresentado como o poeta que profetizou "a profunda verdade - que a religião católica é sempre moderna: ela detesta o velho, mas conserva o antigo" (grifos do autor).

Nessas observações estão contidas não somente declarações sobre a dogmática como também traços profundos da concepção de uma poesia moderna e católica.

O presente de um homem é [...] um resultado do seu próprio passado e dos seus antecessores. Os momentos e as épocas não são estanques, são ligados aos movimentos e às épocas passadas. A admirável liturgia católica celebra a vida do homem desde a sua origem até a consumação dos séculos. Uma síntese tão poderosa só pode ser feita pela encarnação de um Deus cuja vida, atos, palavras, paixão e morte e ressurreição a Igreja celebra hoje como há dois mil anos atrás; um Deus que triunfou do espaço e do tempo, e cuja doutrina não está sujeita - como todas as outras sem exceção - à influência das correntes políticas e econômicas de uma época.

Curioso que esse papa Pio X, que no dizer de Apollinaire era o mais moderno de todos os Europeus, foi o condenador do movimento modernista em filosofia, teologia, arte e literatura. Condenou a modernice, muito antes de nós, modernistas exaltados, a condenamos. ${ }^{42}$

Certamente há ecos aqui daquilo que conhecemos como a doutrina Essencialista dos amigos Murilo e Ismael Nery. O que a modernice não pode absorver foi justamente a noção de eterno, a supressão dos tempos, que é, se vê cada vez mais, o denominador comum entre o catolicismo e a poesia para o poeta mineiro.

Outros temas muito importantes para a poesia muriliana, como a da união entre homem e mulher sexualizada e espiritualizada, na mesma medida - paganismo de fundo que poria o católico em contato com o mundo da matéria - são diretamente tratados.

${ }^{41}$ La religion seule est restée toute neuve, la religion / Est restée simple comme les hangars de portaviation. / Seul en Europe tu n'est pas antique, ó christianisme. / L’Européen le plus moderne c'est vous papepiex. Cf. Murilo Mendes, "Poesia Católica", op. cit., ver nota 1.

${ }^{42}$ Idem, ibidem. 
Restaurar a poesia em Cristo não é, como pensam erradamente alguns, desprezar a matéria, bater no peito e enfiar-se na sacristia. É mesmo, o contrário - sair da sacristia. É apreciar, pesar, apalpar, tocar, sentir, ouvir, cheirar tudo o que a vida nos apresenta - e considerar tudo parte integrante do Reino de Deus. [...] A heresia consiste em afirmar que a matéria é uma força cega e que Deus se confunde com ela: não, a matéria é ordenada pelo espírito (e pela técnica), e Deus transcende da natureza, embora lhe esteja intimamente ligado. ${ }^{43}$

Também se revela o projeto (desejo?) de uma Igreja triunfante que se realizaria através da poesia.

Nossa única mestra, a Igreja Católica, nos dá no seu culto cotidiano uma lição materialista de primeira ordem, atacando os nossos sentidos para que aprendamos a sacralizar as coisas objetivas, na esperança da pacificação da matéria que se há de realizar na Igreja triunfante. ${ }^{44}$

Mas tudo isso são os anos 1930; na década de 1950, cada vez mais, a religião vai perdendo terreno junto à sua poética, o que se torna evidente nos esforços despendidos em separar o poeta do católico quando se apresenta na Itália em 1957. ${ }^{45}$ Naquele primeiro momento, ao contrário, as noções de catolicismo, civilização e poesia são intercambiáveis, todas reunidas em um projeto que se quer universal e eterno seja em Florença, em Paris ou no Rio de Janeiro nas primeiras décadas do século XX; o empenho de Murilo ao participar do debate pela imprensa nos faz perceber o quanto ser poeta, católico e brasileiro informa uma situação e circunstância bem palpáveis. ${ }^{46}$ Ao lado disso, é também a crítica às plataformas modernistas as quais, para nos mantermos dentro dos mesmos parâmetros, interpretam o tempo como terreno, humano e efêmero.

Por último, como que enlaçando todos os argumentos e comentários e sugerindo muito mais, Murilo Mendes iguala a poesia católica de Adalgisa Nery a dos "maiores poetas do mundo, sendo um tropeço para os católicos e falsos espiritualistas". O nome de Adalgisa Nery associa-se de imediato aquele mundo carioca católico das relações mais íntimas de Murilo, onde se destaca a Figura de Ismael Nery e as reuniões na casa em São Clemente, no Rio de Janeiro das décadas de 1920 e 1930; na mesma medida, entretanto, esse nome nos alerta sobre o incontornável descompasso: ler o que se publica no jornal de outra época é lê-la através de documentos. Poucas interpretações conseguem dar a dimensão viva de "como foi", naquele tempo. Sem dúvida, entretanto, nessa escolha transparece a efetividade e familiaridade da categoria poesia católica para Murilo Mendes.

Aos poucos, a força dessa linhagem de poesia e de poetas que Murilo conhecia muito bem foi se exaurindo, até que os poemas pararam de circular - como os de

${ }^{43}$ Idem ibidem.

${ }^{44}$ Idem, ibidem.

${ }^{45}$ Ver nota 22.

${ }^{46}$ Cf. Murilo Mendes, "O Eterno nas Letras Brasileiras Modernas", op. cit., ver nota 1. Com a agudeza de crítico literário que já refletira muito sobre a poesia católica no Brasil, identifica nos poetas modernistas traços católicos. 
Adalgisa Nery - ou então, dizendo de outro modo, não são os traços de catolicismo dos poetas modernistas os que sobreviveram e constituíram o que conhecemos de imediato como a lírica moderna no Brasil. Os intelectuais católicos, tão ativos, polêmicos, atuantes deixam de ser visíveis pela dificuldade que eles próprios apresentavam em enxergar o mundo e o país na sua concretude histórica, ${ }^{47}$ ou seja, em resolver o dilema entre estar no mundo e acima do mundo.

${ }^{47}$ Tal aproximação será feita pela Teologia da Libertação. O catolicismo de Murilo Mendes já foi, inúmeras vezes, identificado com essa vertente da Igreja Católica moderna. Entretanto, os artigos escritos para Dom Casmurro sugerem o necessário rigor histórico: o catolicismo muriliano nos anos 1930 e 1940 não é o mesmo daquele dos anos 1950 e 1960. 